\title{
KLASTERISASI ARMADA PERIKANAN SKALA KECIL DI PULAU KEI KECIL BAGIAN TIMUR, KEPULAUAN KEI
}

\section{CLUSTERING FLEETS OF SMALL-SCALE FISHERIES IN EASTERN KEI KECIL ISLAND, KEI ISLANDS}

\author{
Simon M. Picaulima ${ }^{*}$, Eko Sri Wiyono ${ }^{2}$, Mulyono S. Baskoro², \\ \& Mochammad Riyanto ${ }^{2}$ \\ ${ }^{1}$ Program Studi Agribisnis Perikanan, THP-POLIKANT, Langgur, 97611, Indonesia \\ ${ }^{2}$ Departemen Pemanfaatan Sumberdaya Perikanan, FPIK-IPB University, Bogor, 16680, Indonesia \\ "E-mail: picaulima76@gmail.com
}

\begin{abstract}
Policies and regulations with the nature of the multispecies and multigear fleets of small-scale can cause a decrease in the catch in each fishing area. Fishing fleet clustering can provide more effective and efficient information for management actions. This study aims to identify clustering fleets of small-scale fisheries based on the similarity of catch, income, and operational costs. The research method uses survey methods, primary and secondary data types, and the determination of respondents by purposive sampling technique. Analysis of data used is descriptive analysis and Square Euclidean Distance. The results show that the highest catch, income and operational costs during the west season and transition 1 are purse seine, east season and transition 2 are lift net, while the lowest in west season to transition 2 is drift gillnet fleet. In general, in the west season there are 3 large cluster groups, transition season 1 has 2 large cluster groups, east season there are 3 large cluster groups, transition season 2 has 4 large cluster groups. This results showed that the number and structure fleets of small-scale fisheries clustering always changes in every season.
\end{abstract}

Keywords: catch, cluster, income, operational cost

\begin{abstract}
ABSTRAK
Kebijakan dan regulasi dengan sifat armada perikanan skala kecil yang multispesies dan multigear dapat menyebabkan terjadinya penurunan hasil tangkapan di setiap daerah penangkapan ikan. Klasterisasi armada perikanan dapat memberikan informasi yang lebih efektif dan efisien untuk tindakan pengelolaan. Penelitian ini bertujuan mengidentifikasi klasterisasi armada perikanan skala kecil berdasarkan kemiripan hasil tangkapan, pendapatan dan biaya operasional. Metode penelitian menggunakan metode survei, penentuan responden dengan teknik purposive sampling. Analisis data yang digunakan adalah analisis deskriptif dan Square Euclidean Distance. Hasil penelitian mendapatkan hasil tangkapan, pendapatan dan biaya operasional tertinggi pada musim barat dan pancaroba 1 adalah armada purse seine, musim timur dan pancaroba 2 adalah armada bagan, sedangkan terendah pada musim barat sampai pancaroba 2 adalah armada gillnet hanyut. Secara umum pada musim barat terdapat 3 kelompok klaster besar, musim pancaroba 1 terdapat 2 kelompok klaster besar, musim timur terdapat 3 kelompok klaster besar, musim pancaroba 2 terdapat 4 kelompok klaster besar. Berdasarkan hasil penelitian menunjukkan bahwa klasterisasi yang terjadi dalam setiap musim dipengaruhi oleh hasil tangkapan, pendapatan dan biaya operasional. Jumlah dan struktur klasterisasi armada perikanan skala kecil selalu berubah dalam setiap musim.
\end{abstract}

Kata Kunci: biaya operasional, hasil tangkapan, klaster, pendapatan

\section{PENDAHULUAN}

Kepulauan Kei merupakan gugusan pulau-pulau kecil yang berjumlah 149 pulau, secara geografis diapit oleh Wilayah Pengelolaan Perikanan Republik Indonesia (WPP RI) 714 Laut Banda dan WPP RI 718 Laut Arafura, posisi strategis ini membuat per- 
ikanan tangkap skala kecil sangat berkembang. Perikanan skala kecil yang berkembang di pesisir Pulau Kei Kecil memiliki armada penangkapan yang relatif kecil dengan tonase rendah (Mozumder et al., 2018); daerah penangkapan ikan yang tidak jauh dari pantai (Sudarmo et al., 2015); biaya operasional rendah, hasil tangkapan dikonsumsi dan dijual secara lokal (King, 2007); (Malik et al., 2019); keberadaannya tergantung sumber daya lokal dan dipengaruhi oleh lingkungan (Mc Clanahan et al., 2009); (Malik et al., 2019). Kondisi ini sangat didukung oleh pemerintah dengan berbagai kebijakan dan regulasi, diantaranya peningkatan investasi (input), tidak diwajibkan untuk melaporkan ukuran armada dan hasil tangkapan.

Peningkatan input dan kapasitas armada penangkapan dalam perikanan skala kecil yang bersifat multispesies dan multigear, serta lemahnya pengelolaan perikanan telah mengakibatkan terjadinya kecenderungan penurunan hasil tangkapan di Kepulauan Kei. Menurut data DKP Malra (2014) bahwa sumber daya ikan ekonomis penting pada beberapa daerah penangkapan di wilayah pesisir (0-4 mil) di Kepulauan Kei telah melampaui Jumlah Tangkapan yang Diperbolehkan (JTB). Eksploitasi bersama terhadap sumber daya milik bersama yang tidak dikelola dengan baik, dikhawatirkan dapat mengancam kelestarian ketersediaan stok ikan (Atmaja \& Sadhotomo, 2012). Apabila kondisi ini berlangsung terus menerus ditengah semakin menurunnya sumber daya ikan di daerah penangkapan (04 mil) di Kepulauan Kei, maka dapat menimbulkan beberapa permasalahan yakni memicu terjadinya kompetisi antar nelayan dalam kegiatan penangkapan (Budiarti et al., 2015), degradasi kelimpahan dan ekologi ikan di beberapa daerah penangkapan (Berkes et al., 2001), dan akan berdampak pada overcapacity dan overfishing (Pomeroy, 2011).

Kompetisi armada penangkapan yang tinggi menunjukkan bahwa pemanfaat- an sumber daya perikanan cenderung mengarah pada terjadinya gejala kelebihan kapasitas (Hufiadi \& Wiyono, 2009). Sumber daya ikan yang terbatas membuat nelayan selalu berusaha meningkatkan kemampuan kapal melalui peningkatan input produksi untuk memenangkan kompetisi (Madau et $a l$. , 2009). Oleh karena itu, untuk mewujudkan perikanan skala kecil yang efisien perlu dilakukan pengurangan jumlah input produksi ke level optimal dari kapasitas operasi penangkapan melalui klasterisasi armada perikanan skala kecil berdasarkan karakteristik fungsi alat tangkap, yang meliputi: hasil tangkapan, pendapatan dan biaya operasional. Klasterisasi merupakan bentuk pengelompokan objek (armada perikanan skala kecil) berdasarkan kemiripan karakteristiknya (fungsi armada penangkapan) dalam setiap musim. Klasterisasi digunakan untuk mengetahui kedekatan hubungan alat tangkap berdasarkan kemiripan hasil dan jumlah hasil tangkapan (Wiyono, 2012). Terklasternya beberapa armada perikanan skala kecil ke dalam satu klaster dengan jarak yang sama menunjukkan bahwa pada beberapa armada perikanan skala kecil mempunyai kemiripan dalam karakteristiknya, selain itu menunjukkan bahwa adanya kompetisi pada beberapa armada perikanan skala kecil terhadap sumber daya ikan atau hasil tangkapan yang sama dalam setiap musim. Sebaliknya apabila salah satu atau semua karakteristik fungsi armada perikanan skala kecil berbeda maka armada penangkapan tersebut akan memiliki jarak klaster yang berbeda dengan armada lainnya sehingga armada tersebut akan berada pada klaster tersendiri dalam setiap musim. Semakin jauh jarak klaster ke arah kanan, maka cenderung untuk tidak saling berkompetisi, sebaliknya semakin merapatnya jarak klaster ke arah kiri, maka antar alat tangkap semakin berkompetisi secara ketat (Hakim et al., 2018). Apabila beberapa alat tangkap terkelompok menjadi satu klaster, maka diduga alat tangkap tersebut memiliki kedekatan hubungan dan terjadi kompetisi (Sari 
et al., 2015). Berdasarkan data dan informasi hasil klaster tersebut maka pihak pengelola perikanan dapat melakukan upaya pengelolaan armada perikanan skala kecil yang saling berkompetisi dalam setiap musim.

Penelitian yang terkait dengan klasterisasi perikanan skala kecil sebelumnya pernah dilakukan berdasarkan komposisi dan keragaman hasil tangkapan (Sari et al., 2015); berdasarkan hasil tangkapan, kapasitas armada dan daerah penangkapan (Hakim et al., 2018); berdasarkan jumlah nelayan, rumah tangga perikanan, jumlah armada, alat penangkap ikan, jumlah produksi ikan, dan nilai produksi ikan, nilai pengeluaran ikan (Yuniati \& Rahman, 2017); berdasarkan enam aspek pembangunan perikanan, yaitu: aspek alam, manusia, fisik, keuangan, sosial dan kelembagaan (Vatria et al., 2019). Klasterisasi yang dilakukan berdasarkan fungsi armada perikanan untuk mengatasi kompetisi armada perikanan skala kecil dalam setiap musim di Kepulauan Kei belum pernah dilakukan, sehingga tujuan dari penelitian ini adalah mengidentifikasi dan mengklasterisasi armada perikanan ska- la kecil dalam setiap musim berdasarkan fungsi armada penangkapan. Penelitian ini dapat memberikan data dan informasi yang lebih efektif dan efisien mengenai jumlah input yang optimal dalam setiap musim berdasarkan fungsi armada penangkapan skala kecil, sehingga dapat dijadikan sebagai alternatif kebijakan bagi pemerintah dan nelayan untuk memilih dan menetapkan standardisasi alat tangkap yang lebih praktis dan ramah lingkungan dalam pengoperasiannya untuk keberlanjutan usaha perikanan dan stok sumber daya ikan di Kepulauan Kei.

\section{METODE PENELITIAN}

\subsection{Waktu dan Lokasi}

Penelitian ini dilaksanakan pada bulan Oktober 2019-Maret 2020 di Pulau Kei Kecil bagian timur, Kepulauan Kei, dengan lokasi pengambilan sampel di 13 Ohoi (Desa) yaitu: Ohoi Sitniohoi, Ohoi Dunuwahan, Ohoi Letman, Ohoi Faer, Ohoi Ohoijang, Ohoi Faan, Ohoi Sathean, Ohoi Disuk, Ohoi Revav, Ohoi Raat, Ohoi Mastur, Ohoi Elar dan Ohoi Danar (Figure 1).

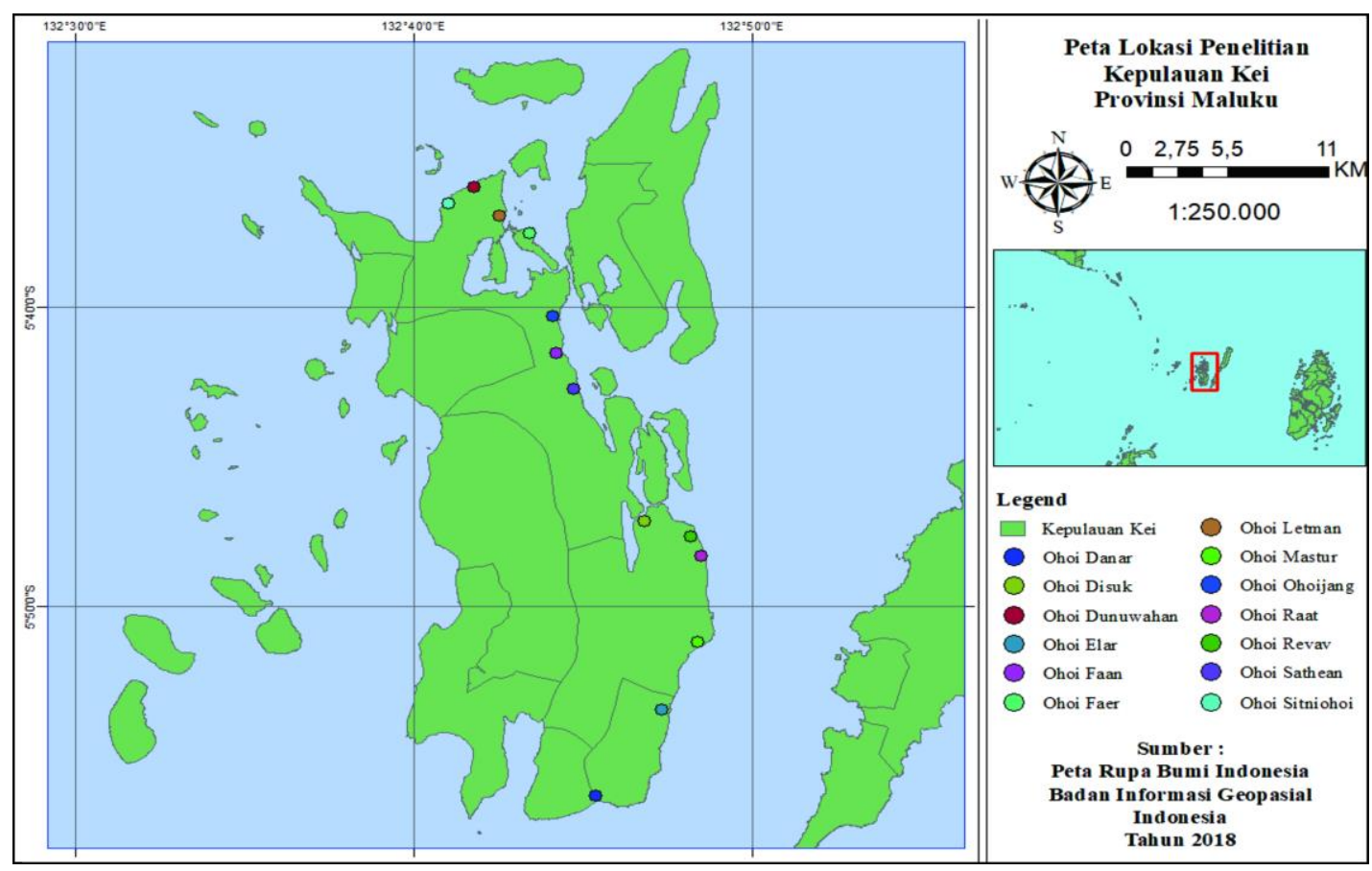

Figure 1. The research location in Eastern Kei Kecil Island, Kei Island. 


\subsection{Jenis dan Metode Pengumpulan Data}

Data yang digunakan meliputi data daerah penangkapan, hasil tangkapan, pendapatan, biaya operasional dalam setiap musim. Pengumpulan data dilakukan dengan metode survei dengan teknik wawancara, kuesioner dan observasi. Penentuan responden berdasarkan teknik purposive sampling terhadap nelayan kecil yang memiliki pengalaman melaut lebih besar dari lima tahun $\left(>5^{\text {th }}\right)$ dan aktif dalam mengoperasikan armada penangkapan ikan dalam setiap musim dengan kapasitas kurang dari 10 GT $(<10$ GT) sesuai dengan UU RI Nomor 7 Tahun 2016, diperoleh 102unit armada perikanan skala kecil yang meliputi armada bagan apung, purse seine, pancing ulur, pancing tegak, pancing tonda, gillnet dasar, dan gillnet hanyut.

\subsection{Analisis Data}

\subsubsection{Analisis Deskriptif}

Analisis deskriptif dalam penelitian ini digunakan untuk menganalisis daerah penangkapan, hasil tangkapan, pendapatan dan biaya operasional. Hasilnya disajikan dalam bentuk histogram (Figure 4-6).

Identifikasi daerah penangkapan ikan untuk mengetahui daerah penangkapan ikan dalam setiap musim. Identifikasi ini dilakukan melalui peta grid dan ditunjukkan ke nelayan sebagi responden, kemudian nelayan menandai lokasi penangkapan setiap musim. Selanjutnya, ditransformasikan ke dalam software Arc Map untuk menghasilkan peta daerah penangkapan ikan setiap musim. Analisis pendapatan armada penangkapan ikan dilakukan setelah mendapat data dan informasi pendapatan armada penangkapan ikan dalam setiap musim. Pendapatan armada adalah perkalian harga jual ikan dengan jumlah produksi armada penangkapan (Charles, 2001), yakni:

$$
T R=p \cdot Y
$$

Keterangan: $T R=$ Penerimaan total $(\mathrm{Rp} /$ musim); $p=$ Harga jual ikan (Rp/kg); $Y=$ Produksi tangkapan (kg). Kemudian ditabulasi dan diolah dengan Microsoft Excel serta disajikan dalam bentuk histogram setiap musim.

Identifikasi komposisi hasil tangkapan meliputi jenis dan jumlah ikan hasil tangkapan berdasarkan jenis armada penangkapan yang dilakukan setiap musim, informasi jenis dan jumlah ikan hasil tangkapan selanjutnya ditabulasi dan diolah dengan Microsoft Excel serta disajikan dalam bentuk tabel dan histogram setiap musim.

Analisis biaya operasional armada penangkapan ikan dalam perikanan skala kecil dilakukan setelah mendapat informasi biaya operasional armada penangkapan ikan dalam setiap musim. Analisis total biaya operasional per musim merupakan perkalian antara jumlah biaya satuan untuk armada yang dikeluarkan untuk penangkapan dengan besar upaya penangkapan (Charles, 2001).

$T C=c . E$.

Keterangan: $T C=$ Biaya operasional penangkapan total (Rp/musim); $c=$ Biaya yang dikeluarkan dalam setiap kegiatan operasi penangkapan (Rp/musim); $E=$ Jumlah trip penangkapan ikan (trip/musim). Selanjutnya ditabulasikan dan diolah dengan Microsoft Excel, serta disajikan dalam bentuk histogram dalam setiap musim.

\subsubsection{Analisis Klasterisasi}

Analisis klasterisasi armada perikanan skala kecil digunakan untuk menganalisis data hasil tangkapan, pendapatan dan biaya produksi dalam setiap musim dengan menggunakan software SPSS 23. Hasilnya disajikan dalam bentuk dendogram (Figure 7-10). Rumus squared euclidean distance (Yulianto \& Hidayatulah, 2014):

$d(x, y)=\sqrt{\left(\sum_{i=1}^{d}\left(x_{1}-y_{1}\right)^{2}\right.}$

Keterangan: $x=\left(x_{1}, x_{2}, x_{3}, \ldots \ldots x_{d}\right) ; y=\left(y_{1}, y_{2}\right.$, 
$\left.y_{3}, \ldots \ldots y_{d}\right)$.

\section{HASIL DAN PEMBAHASAN}

\subsection{Daerah Penangkapan Armada Perikanan Skala Kecil}

Daerah penangkapan armada perikanan skala kecil dapat dilihat pada Figure $3 a$ musim barat, Figure $3 b$ musim pancaroba 1, Figure $3 c$ musim timur, dan Figure $3 c$ musim pancaroba 2. Daerah penang-

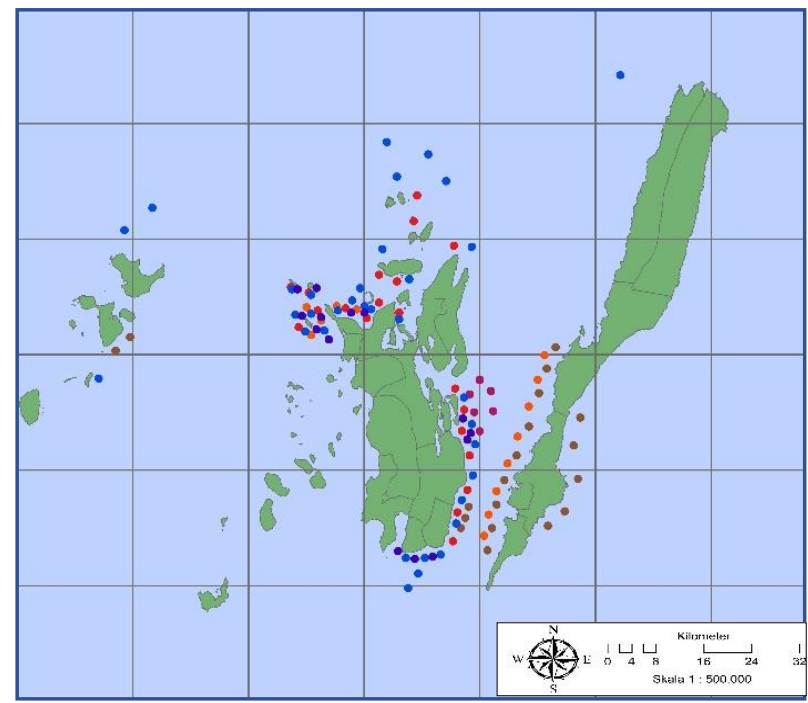

(a) West season

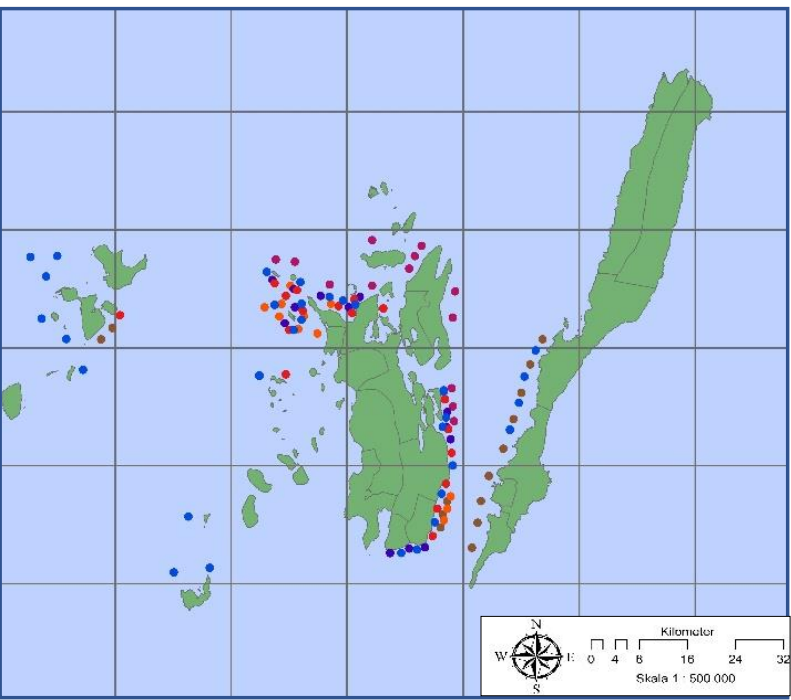

(c) East season kapan armada purse seine, pada musim barat sampai musim timur di pesisir barat Pulau Kei Besar dan timur Pulau Tayando, sedangkan pada bagian timur Pulau Kei Besar mulai dari musim barat sampai pancaroba 1. Daerah penangkapan armada bagan apung dari musim barat sampai pancaroba 1 di bagian timur Pulau Kei Kecil, kemudian pada musim timur berpindah ke arah utara timur Pulau Kei Kecil dan kembali lagi pada musim pancaroba 2 ke bagian timur.

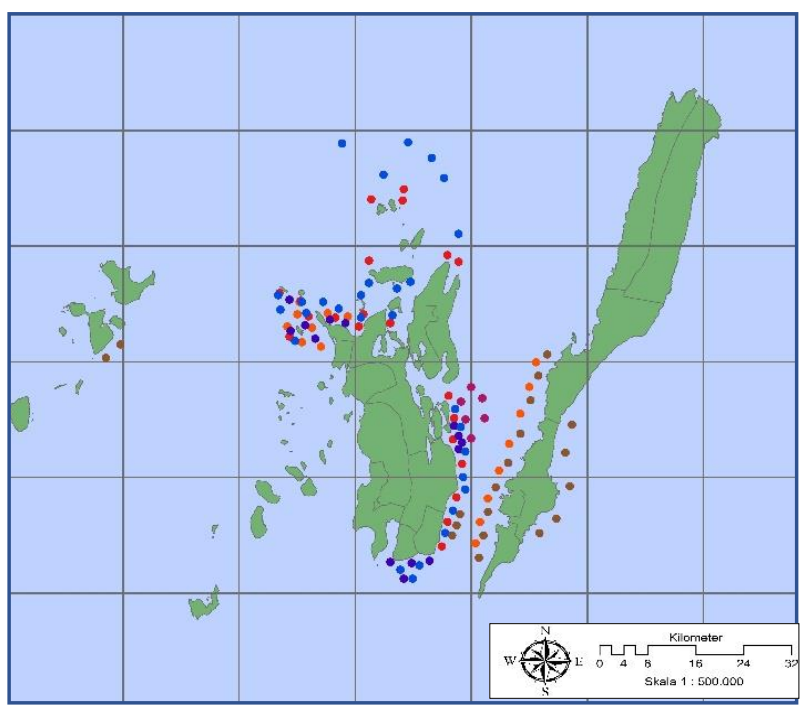

(b) Transition period 1

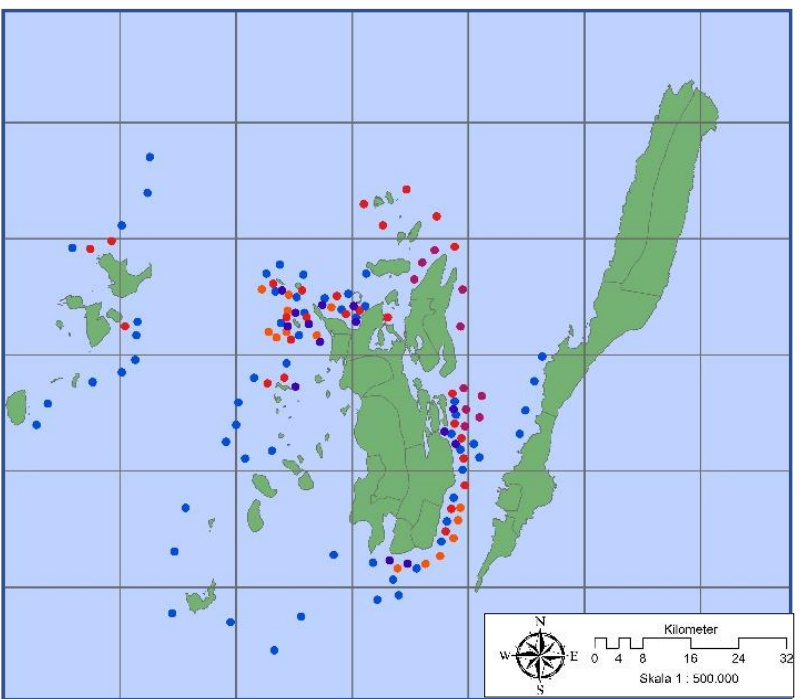

(d) Transition period 2

Legend: • Lift net $\bullet$ Hand line $•$ Purse seine $\bullet$ Troll line $\bullet$ Bottom gillnet $\bullet$ Drift gillnet

Figure 3. Fishing ground fleets of small scale fisheries in west season, transition period 1, east season and transition period 2. Eastern Kei Kecil Island, Kei Island. 
Daerah penangkapan armada pancing ulur dari musim barat sampai musim pancaroba 1 berada di bagian timur, utara dan selatan Pulau Kei Kecil, pada musim timur sampai awal musim barat sebagian armada berada di bagian barat Pulau Kei Kecil dan Tayando.

Daerah penangkapan armada gillnet dasar dari musim barat sampai musim pancaroba 1 berada di bagian timur dan utara Pulau Kei Kecil, kemudian dari musim timur sampai awal musim barat berada di bagian barat Pulau Kei Kecil. Daerah penangkapan armada gillnet hanyut dari musim barat sampai musim pancaroba 2 berada di pesisir bagian timur, selatan dan utara Ohoi dan Pulau Kei Kecil. Daerah penangkapan armada pancing tonda yang berada di bagian timur Pulau Kei Kecil dari musim barat sampai musim pancaroba 1 berada di pesisir barat Pulau Kei Besar, kemudian pada musim timur sampai pancaroba 2 berada di pesisir timur selatan Pulau Kei Kecil. Daerah penangkapan bagian utara dari musim barat sampai pancaroba 2 berada di pesisir Ohoi dan pulau-pulau kecil.

\subsection{Hasil Tangkapan Armada Perikanan Skala Kecil}

Pada Figure 4 menunjukkan bahwa musim barat hasil tangkapan tertinggi adalah armada purse seine sebesar 33.922 $\mathrm{kg}$ dan musim pancaroba 1 sebesar 27.121 $\mathrm{kg}$, sedangkan hasil tangkapan terendah pada musim barat adalah armada gillnet hanyut sebesar $873 \mathrm{~kg}$ dan musim pancaroba 1 adalah armada gillnet hanyut sebesar $569 \mathrm{~kg}$. Pada musim timur hasil tangkapan tertinggi adalah armada bagan apung sebesar $29.439 \mathrm{~kg}$ dan $\mathrm{kg}$. Musim pancaroba 2 sebesar $21.851 \mathrm{~kg}$, sedangkan hasil tangkapan terendah pada musim timur adalah armada gillnet hanyut sebesar $678 \mathrm{~kg}$ dan pancaroba 2 sebesar 1.271

\subsection{Pendapatan Armada Perikanan Skala Kecil}

Pada Figure 5 menunjukkan bahwa pendapatan armada perikanan skala kecil yang tertinggi di musim barat adalah purse seine sebesar Rp407.054.000,00 dan musim pancaroba 1 sebesar Rp366.130.000,00, sedangkan pendapatan terendah armada perikanan gillnet hanyut pada musim barat adalah sebesar Rp11.202.150,00 dan musim pancaroba 1 sebesar Rp8.142.683,00. Armada perikanan bagan apung merupakan alat tangkap yang memiliki pendapatan tertinggi pada musim timur sebesar Rp264.977.800,00 dan musim pancaroba 2 sebesar Rp201.028.200,00 sedangkan pendapatan terendah pada musim timur dan pancaroba 2 adalah armada gillnet hanyut yakni sebesar Rp9.076.717,00 dan

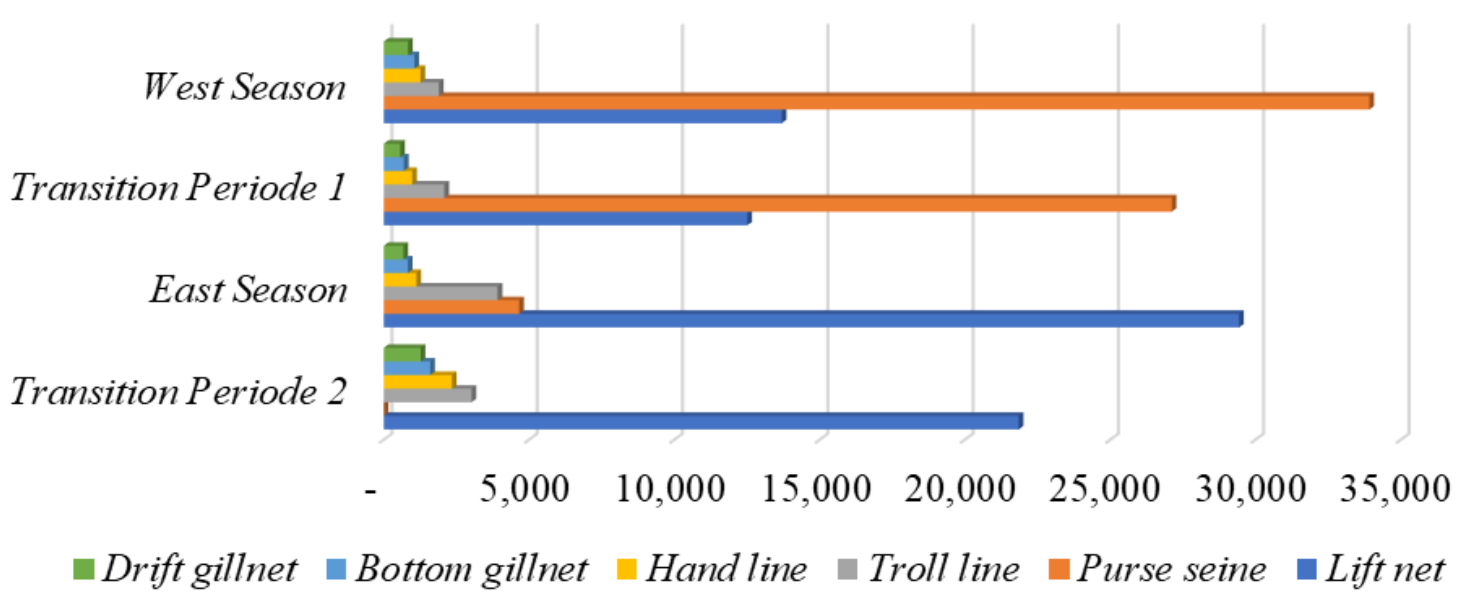

Figure 4. Average catch fleets of small scale fisheries in every season, Eastern Kei Kecil Island, Kei Island. 


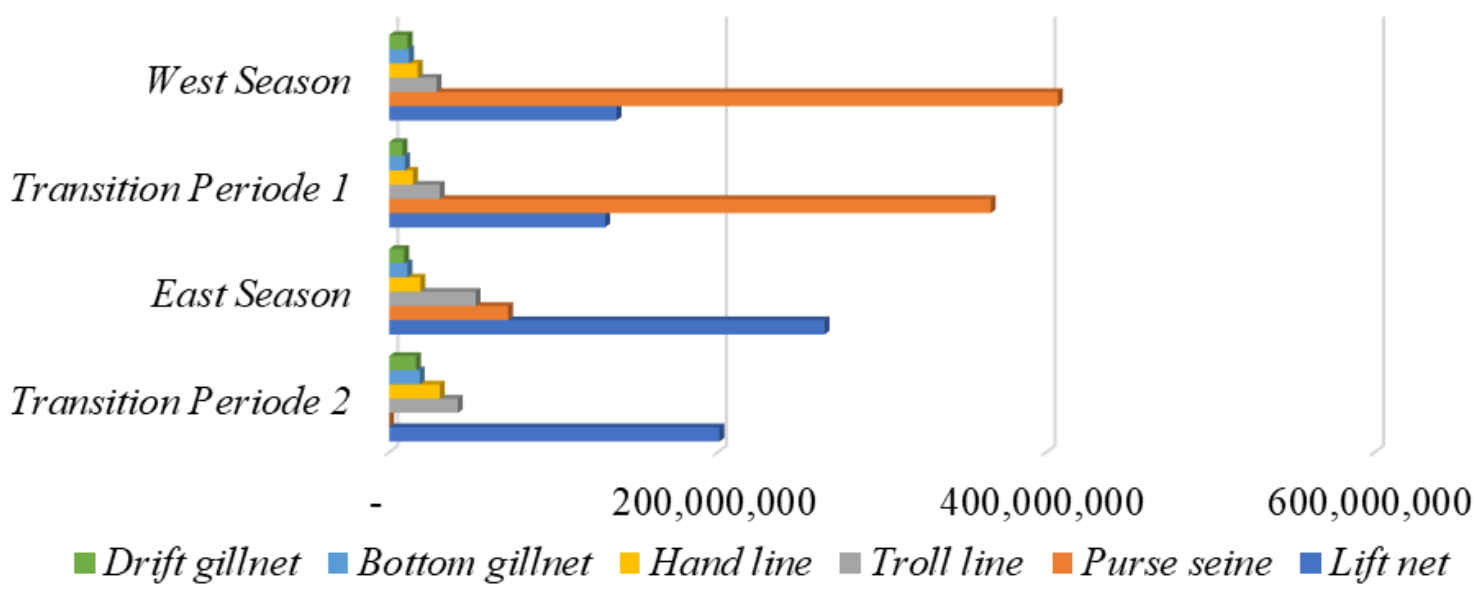

Figure 5. Average income of small scale fisheries in every season, Eastern Kei Kecil Island, Kei Island.

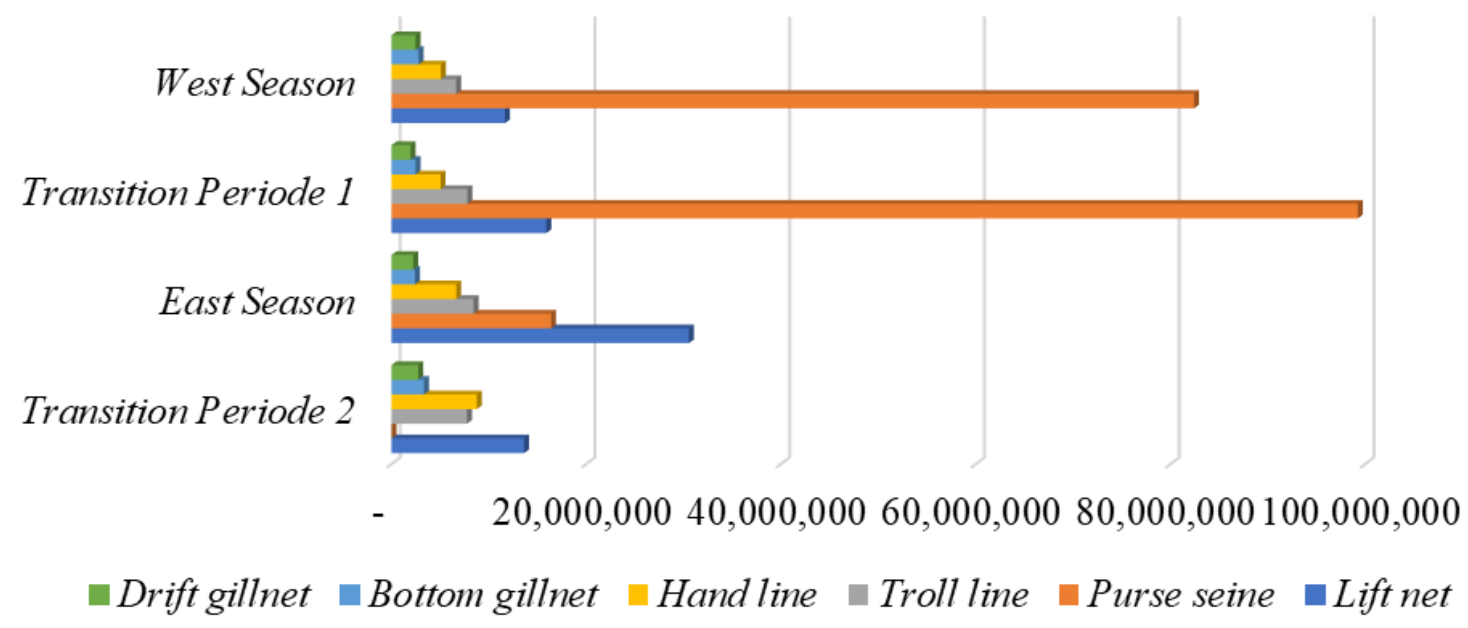

Figure 6. Average operating cost of small scale fisheries in every season, Eastern Kei Kecil Island, Kei Island.

Rp16.332.200,00.

\subsection{Biaya Operasional Armada Perikanan Skala Kecil}

Pada Figure 6 menunjukkan bahwa armada perikanan purse seine memiliki biaya operasional yang tertinggi pada musim barat Rp82.408.500,00 dan musim pancaroba 1 Rp99.235.833,00. Pada musim timur dan pancaroba 2 biaya operasional yang tertinggi adalah armada penangkapan bagan apung sebesar Rp30.553.333 dan Rp13.616.500,00. Biaya operasional teren- dah pada musim barat sampai musim pancaroba 2 adalah armada gillnet hanyut pada musim barat sebesar 2.483.667, musim pancaroba 1 sebesar Rp1.957.333,00 musim timur sebesar Rp2.225.000,00 dan musim pancaroba 2 sebesar Rp2.742.667,00.

\subsection{Klasterisasi Armada Perikanan Skala Kecil}

Pola klasterisasi armada perikanan skala kecil selalu berubah dalam setiap musim, pada musim barat terdapat 3 klaster utama yakni: klaster pertama armada purse 


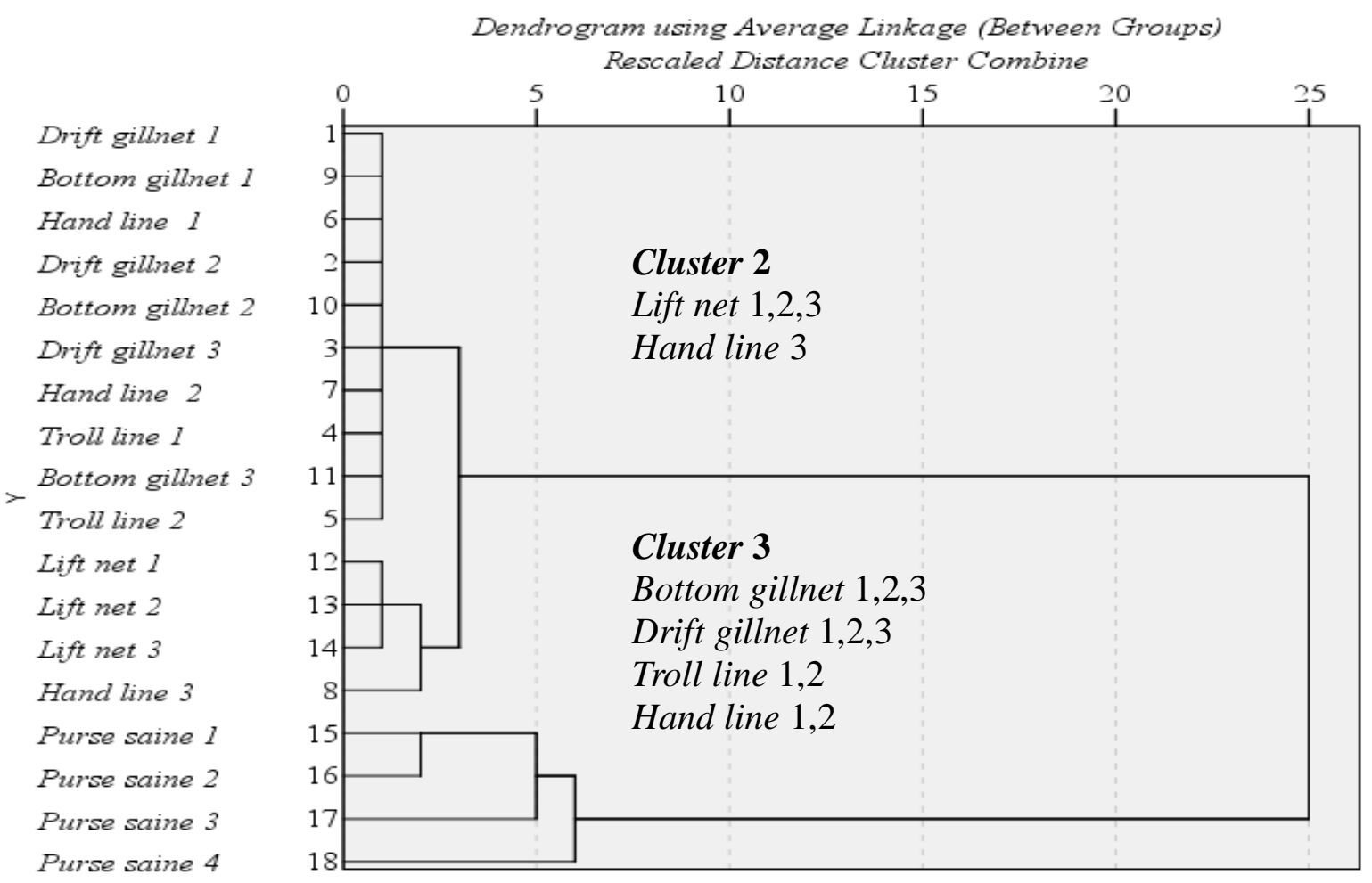

Figure 7. Dendrogram using average link age between fleets of small scale fisheries in west season, Eastern Kei Kecil Island, Kei Island.

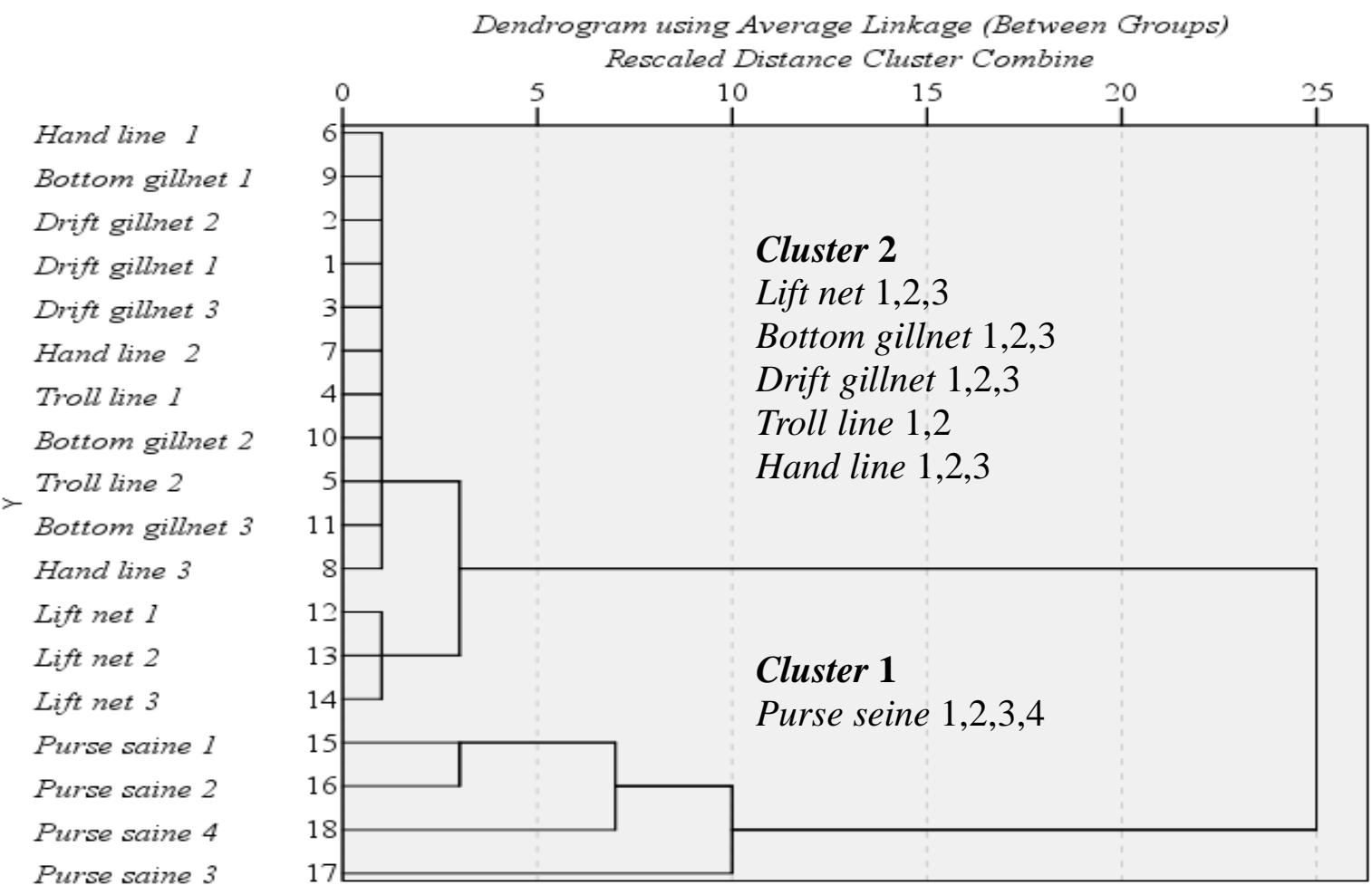

Figure 8. Dendrogram using average linkage between fleets of small scale fisheries in transition period 1, Eastern Kei Kecil Island, Kei Island. 


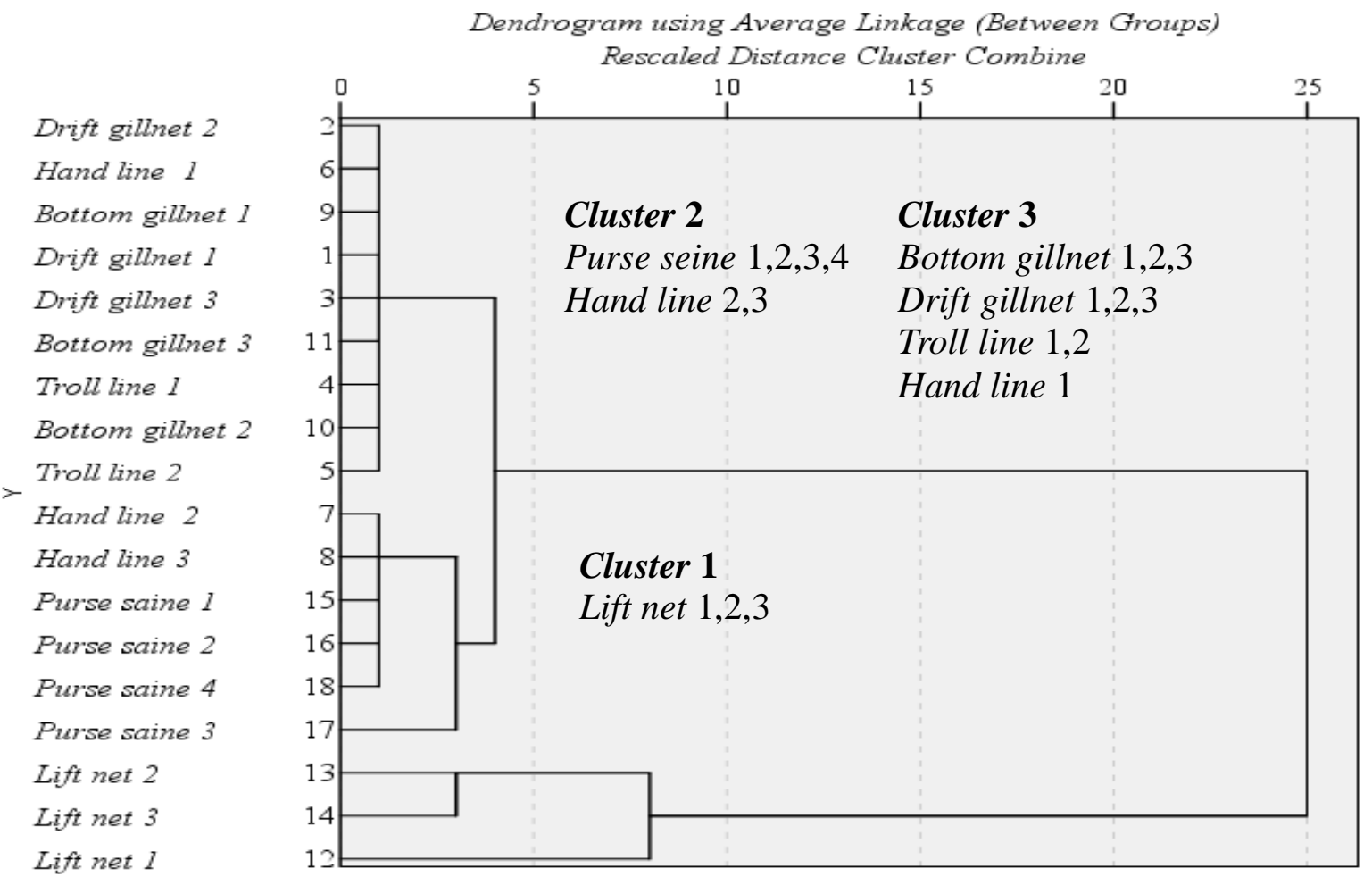

Figure 9. Dendrogram using average linkage between fleets of small scale fisheries in east season, Eastern Kei Kecil Island, Kei Island.

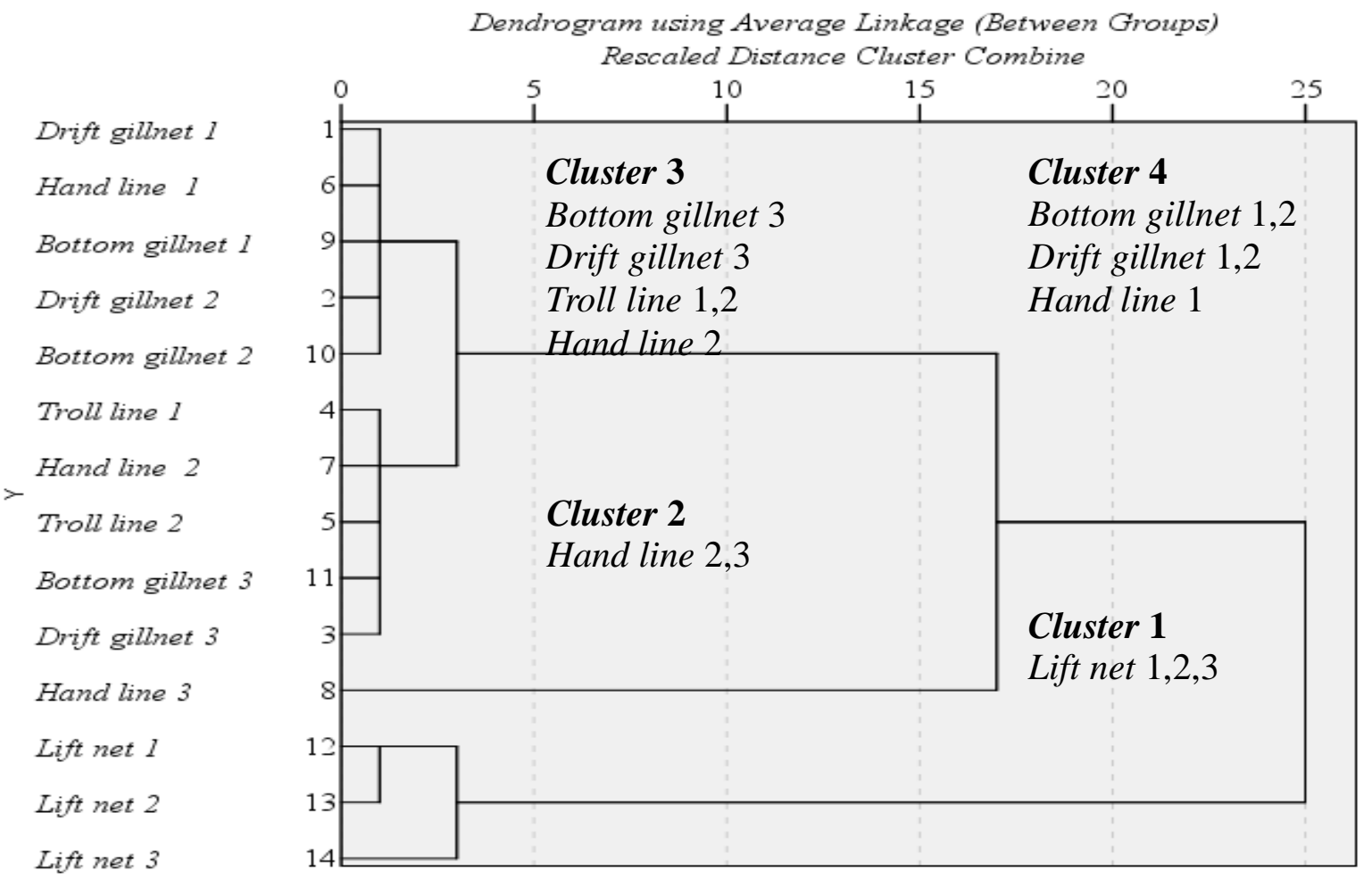

Figure 10. Dendrogram using average linkage between fleets of small scale fisheries in transition period 2, Eastern Kei Kecil Island, Kei Island. 
seine, klaster kedua adalah armada bagan apung dan sebagian pancing ulur, dan klaster ketiga meliputi armada gillnet dasar, gillnet hanyut, pancing tonda dan sebagian pancing ulur (Figure 7). Musim pancaroba 1 terdapat 2 klaster utama yakni: klaster pertama adalah armada purse seine dan klaster kedua meliputi armada bagan apung bersama dengan armada pancing ulur, pancing tonda, gillnet hanyut dan gillnet dasar (Figure 8). Musim timur, terdapat 3 klaster utama yakni: klaster pertama armada bagan apung, klaster kedua armada purse seine dan sebagian armada pancing ulur, klaster ketiga sebagian pancing ulur, pancing tonda, gillnet hanyut dan gillnet dasar (Figure 9). Pada musim pancaroba 2 terdapat 4 klaster utama yakni armada bagan apung pada klaster 1, sebagian armada pancing ulur pada klaster kedua, sebagian armada gillnet hanyut, gillnet dasar, pancing tonda dan pancing ulur, sedangkan pada klaster keempat meliputi sebagian armada pancing ulur, armada gillnet dasar dan gillnet hanyut (Figure 10).

\subsection{Pembahasan}

Musim barat angin bertiup dari arah utara-barat laut ke arah timur tenggara, sehingga kondisi laut bagian timur kurang bergelombang, pada musim ini daerah penangkapan nelayan kecil di bagian timur Pulau Kei Kecil agak jauh dari pantai sedangkan pada bagian utara dan selatan dekat dengan pantai. Sebaliknya pada musim timur, angin bertiup dari timur tenggara ke arah utara-barat laut sehingga kondisi laut kurang bergelombang sehingga daerah penangkapan nelayan kecil di bagian utara dan selatan agak jauh dari pesisir Ohoi dan pulau-pulau kecil bahkan meluas ke bagian barat Pulau Kei Kecil, sedangkan daerah penangkapan nelayan di bagian timur Pulau Kei Kecil dekat dengan pesisir Ohoi. Menurut Harahap et al. (2019) bahwa jika cuaca bergelombang dan arus yang tinggi maka nelayan akan melakukan operasi penangkapan ikandekat dengan pesisir Ohoi dan pulau-pulau kecil agar terlindung dari gelombang tinggi, sebaliknya jika cuaca tidak bergelombang dan arus yang tidak tinggi maka nelayan akan melakukan operasi penangkapan ikan agak jauh dari pantai. Musim pancaroba 1 dan pancaroba 2, arah angin yang bertiup tidak menentu membuat perairan kurang bergelombang, namun kecepatan angin di musim pancaroba 1 tinggi dibandingkan musim pancaroba 2. Pada musim pancaroba 1 maupun pancaroba 2 , semua armada penangkapan yang home base di Pulau Kei Kecil bagian timur, utara dan selatan dapat melakukan operasi penangkapan agak jauh dari pantai bahkan sampai ke bagian barat Pulau Kei Kecil pada musim pancaroba 2 .

Daerah penangkapan yang cocok dan menguntungkan secara ekonomi dalam usaha penangkapan akan memberikan hasil tangkapan ikan yang tinggi. Oleh karena itu, ciri-ciri daerah penangkapan ikan yang baik adalah terdapat sumber daya ikan yang memiliki nilai ekonomis tinggi (Ayodhyoa, 1981). Hasil tangkapan ikan yang tinggi pada armada purse seine di musim barat dan pancaroba 1 karena pada musim tersebut adalah musim penangkapan ikan momar (Decapterus russelli) yang merupakan hasil tangkapan utama armada purse seine dengan menggunakan rumpon sebagai alat bantu penangkapan ikan sekaligus sebagai daerah penangkapan ikan. Hasil tangkapan tertinggi pada musim timur dan musim pancaroba 2 pada armada penangkapan bagan apung disebabkan karena musim penangkapan ikan teri (Stolephorus spp.) dan daerah penangkapannya mengikuti arah ruaya ikan teri (Stolephorus spp.) untuk memaksimalkan hasil tangkapan. Hasil tangkapan nelayan kecil yang maksimal selalu dinamis di antara beberapa daerah penangkapan ikan (Matić-Skoko et al., 2011). Armada perikanan skala kecil di Pulau Kei Kecil bagian timur didominasi oleh armada penangkapan purse seine, bagan, pancing tonda, gillnet hanyut, gillnet dasar. Sifat alat tangkap yang multi-gear dan multispesies membuat kom- 
petisi semakin tinggi dalam memaksimalkan hasil tangkapan, baik untuk hasil tangkapan utama maupun hasil tangkapan sampingan (by catch dan discards).

Pendapatan armada merupakan pendapatan yang diperoleh dari penjualan hasil tangkapan (pendapatan kotor), karena itu pendapatan armada perikanan skala kecil sangat tergantung pada hasil tangkapan yang diperoleh. Tingginya pendapatan armada purse seine pada musim barat dan pancaroba 1 karena hasil tangkapannya lebih tinggi dibandingkan armada penangkapan lainnya, begitu pula untuk armada bagan apung pada musim timur dan pancaroba 2. Sebaliknya, untuk armada gillnet hanyut di musim barat sampai pancaroba 2 . Tinggi hasil tangkapan nelayan akan berdampak pada pendapatan nelayan, hasil tangkapan yang tinggi membuat nelayan dapat menjual ikan dalam jumlah yang banyak sehingga pendapatan nelayan makin tinggi (Dahar, 2016). Sebaliknya jika hasil tangkapan menurun maka pendapatan armada perikanan juga mengalami penurunan (Soukota, 2013). Tingginya biaya operasional armada penangkapan purse seine pada musim barat, pancaroba 1 dan timur karena dalam operasi penangkapan ikan armada penangkapan purse seine menggunakan 2 kapal (two boat system), jumlah trip terus meningkat terutama musim pancaroba 1, kapasitas armada purse seine mini dan jumlah $\mathrm{ABK}$ yang banyak (15-17 orang) saat operasi penangkapan. Biaya operasional yang tinggi pada armada bagan di musim timur dan pancaroba 2 karena daerah penangkapan yang agak jauh, peningkatan jumlah $\mathrm{ABK}$ dan jumlah hauling saat musim ikan teri (Stolephorus spp.). Biaya operasional terendah pada armada gillnet hanyut pada musim barat hingga musim pancaroba 2, karena jarak ke daerah penangkapan tidak terlalu jauh, kapasitas armada tidak terlalu besar, jumlah ABK tidak terlalu banyak (1-3 orang), waktu operasi penangkapan tidak terlalu lama. Biaya operasional yang dibutuhkan dalam operasi penangkapan sangat tergantung pada jarak ke daerah penangkapan, lamanya operasi penangkapan, kapasitas armada dan jumlah ABK. Daerah penangkapan yang terbatas 1-4 mill, one day one fishing, kapasitas armada yang kecil (<10 GT) dan jumlah ABK yang terbatas membuat biaya operasional armada perikanan di Pulau Kei Kecil bagian timur tidak terlalu besar. Biaya operasi penangkapan yang rendah membatasi nelayan dalam operasi penangkapan (Fathanah et al., 2013).

Pola klasterisasi armada perikanan skala kecil di Kepulauan Kei selalu berubah dalam setiap musim, perubahan ini sangat dipengaruhi oleh karakteristik fungsi alat tangkap dalam armada perikanan skala kecil yang meliputi produksi hasil tangkapan (biologis), pendapatan armada (tekno sosek) dan biaya operasional (ekonomi). Menurut Sudarmo et al. (2013) nelayan kecil selalu mencari daerah penangkapan ikan yang dapat menangkap ikan dalam jumlah banyak, sehingga memberikan pendapatan tinggi dari biaya operasional. Akibatnya, upaya penangkapan nelayan kecil selalu dinamis dalam setiap musim, kondisi ini merupakan bagian dari strategi penangkapan ikan yang diterapkan oleh nelayan kecil dalam mengalokasikan alat tangkap sebagai bentuk adaptasi terhadap perubahan faktor eksternal (musim dan lingkungan/iklim) (Wiyono et al., 2006; Chodriyah \& Wiyono, 2011).

Musim barat terdapat 3 klaster utama, karena pola iklim (curah hujan dan kecepatan angin) dan musim yang terjadi pada musim barat di Pulau Kei Kecil bagian timur sehingga hasil tangkapan dan pendapatan armada yang diperoleh lebih besar dari biaya operasional yang dikeluarkan. Pada musim pancaroba 1 terdapat 2 klaster utama, walaupun lautan kurang bergelombang pada bagian timur Pulau Kei Kecil namun kecepatan angin pada musim ini masih tinggi dan produktivitas perairan yang semakin menurun. Kondisi ini sangat memengaruhi hasil tangkapan, pendapatan dan biaya operasional. Musim timur terdapat 3 klaster utama, tingginya produktivitas per- 
airan akibat peningkatan klorofil-a dan upwelling, mengakibatkan operasi penangkapan bagan apung meluas ke arah timur dan utara laut Pulau Kei Kecil, armada pancing ulur dan gillnet dasar meluas ke bagian barat Pulau Kei Kecil kondisi ini sangat memengaruhi peningkatan biaya operasional, hasil tangkapan, pendapatan ketiga armada tersebut. Hal yang sama juga terjadi pada musim pancaroba 2 untuk armada pancing ulur, gillnet dasar dan gillnet hanyut yang kapasitannya besar. Armada perikanan skala kecil dengan kapasitas yang kecil akan berada di pesisir Ohoi dan pulau-pulau kecil bagian utara, timur dan selatan Pulau Kei Kecil dari musim barat sampai musim pancaroba 2.

Pada musim barat dan pancaroba 1 armada purse seine berada di klaster tersendiri, sedangkan pada musim timur dan pancaroba 2 armada bagan apung berada di klaster tersendiri, kondisi ini dipengaruhi oleh musim penangkapan ikan, musim angin, jarak daerah penangkapan, kapasitas armada dan waktu operasi penangkapan (Hakim et al., 2018); karakteristik teknis kapal dan jumlah kru (Le Pape \& Vigneau, 2001). Klaster 3 (gillnet dasar, gillnet hanyut, pancing tonda, sebagian pancing ulur) di musim barat, klaster 2 (pancing ulur, gillnet dasar, gillnet hanyut, pancing tonda) di musim pancaroba 1, klaster 3 (gillnet dasar, gillnet hanyut, pancing tonda, pancing ulur) di musim timur, dan klaster 3 (gillnet dasar, gillnet hanyut, pancing tonda, pancing ulur) dan klaster 4 sebagian (gillnet dasar, gillnet hanyut, pancing ulur) memiliki jarak klaster yang sama karena memiliki kemiripan yang dekat dalam karakteristik fungsi armada penangkapan, kondisi ini menunjukan bahwa adanya kompetisi (interaksi) antar armada perikanan skala kecil terhadap sumber daya ikan yang sama. Kompetisi armada perikanan skala kecil dapat terjadi karena daerah penangkapan yang tidak terlalu jauh akibat musim angin, musim ikan, teknologi penangkapan, kondisi sumber daya ikan, serta kapasitas armada (Hakim et al., 2018), komposisi dan keragaman hasil tangkapan yang mirip (Sari et al., 2015).

Hasil klasterisasi menunjukkan bahwa peningkatan jumlah input dan kapasitas armada penangkapan dalam perikanan skala kecil yang bersifat multispesies dan multigear, di daerah penangkapan yang sempit (0-4 mil) dan sumber daya ikan yang semakin menurun telah memicu terjadinya kompetisi armada perikanan dan degradasi kelimpahan dan ekologi ikan di daerah penangkapan ikan, karena itu untuk keberlanjutan usaha perikanan tangkap skala kecil perlu dilakukan pengurangan jumlah variabel input agar diperoleh nilai optimal dari kapasitas operasi penangkapan dalam setiap musim. Kondisi ini merupakan bentuk upaya pengelolaan dengan teknik input dan output kontrol (Bellido et al., 2020).

\section{KESIMPULAN}

Klasterisasi armada perikanan skala kecil di Kepulauan Kei sangat dipengaruhi oleh karakteristik fungsi armada penangkapan yang meliputi hasil tangkapan, pendapatan dan biaya operasional. Hasil klasterisasi armada perikanan skala kecil menunjukkan bahwa musim barat terdapat 3 kelompok klaster besar, musim pancaroba 1 terdapat 2 kelompok klaster besar, musim timur terdapat 3 kelompok klaster besar, musim pancaroba 2 terdapat 4 kelompok klaster besar, armada perikanan skala kecil yang diklasterisasi sama pada penelitian ini diduga berdasarkan pada jarak klaster yang terjadi.

\section{UCAPAN TERIMAKASIH}

Terima kasih yang sebesar-besarnya disampaikan kepada Kementerian Riset, Teknologi dan Pendidikan Tinggi. Lembaga Penjamin Dana Pendidikan (LPDP). WWF Indonesia cabang Kabupaten Maluku Tenggara. Masyarakat Ohoi Dunuwahan, Ohoi Sitniohoi, Ohoi Letman, Ohoi Faer, 
Ohoi Ohoijang, Ohoi Sathean, Ohoi Disuk, Ohoi Revav, Ohoi Rat, Ohoi Mastur, Ohoi Elar dan Ohoi Danar.

\section{DAFTAR PUSTAKA}

Atmaja, S.B. \& B. Sadhotomo. 2012. Kompetisi dan interaksi perikanan: studi kasus pada perikanan layang (Decapterus spp.) di Laut Jawa. J. Penelitian Perikanan Indonesia, 18(3): 197-204.

https://doi.org/10.15578/jppi.18.3.20 12.197-204

Ayodhyoa, A.U. 1981. Metode penangkapan ikan, Yayasan Dewi Sri. Bogor. $97 \mathrm{p}$.

Berkes, F., R. Mahon, P. McConney, R. Pollnac, \& R. Pomeroy. 2001. Managing small scale fisheries: alternative directions and methods. International Development Research Centre. Canada. 321 p.

Bellido, J.M., U. Sumaila, J.L.S. Lizaso, M.L. Palomares, \& D. Pauly. 2020. Input versus output controls as instruments for fisheries management with a focus on Mediteranean fisheries. Marine Policy, 118(1): 1-8. https://doi.org/10.1016/j.marpol.201 9.103786

Budiarti, T.W., E.S. Wiyono, \& N. Zulbainarni. 2015. Produksi optimal pukat cincin di PPN Pemangkat, Kalimantan Barat. J. Litbang Perikanan Indonesia, 21(1): 37-44. http://doi.org/10.15578/jppi.21.1.201 5.37-44

Charles, A.T. 2001. Sustainable fishery systems. Blakwell Science, Ltd. London. 370 p.

Chodriyah, U. \& E.S. Wiyono. 2011. Fishing grounds dynamics of purse seine fisheries in the Java Sea. Indonesia Fisheries Research J., 1: 21-27.

https://doi.org/10.15578/ifrj.17.1.201

\section{$1.21-27$}

Dahar, D. 2016. Faktor-faktor yang mempengaruhi pendapatan nelayan di Desa Pohuwato Timur, Kecamatan Marisa, Kabupaten Puwato. $J$. Agropolitan, 3(3): 9-21.

http://www.faperta.unisan.ac.id/jurn al/index.php/Agropol/article/view/43

Dinas Kelautan dan Perikanan (DKP). Kabupaten Maluku Tenggara. 2014. Laporan Statistik Perikanan Tahun 2014. Pemerintah Daerah Kabupaten Maluku Tenggara. Maluku Tenggara, $150 \mathrm{p}$.

Fathanah, Y., E.S. Wiyono, Darmawan, \& Y. Novita. 2013. Dinamika dan karakteristik unit penangkapan ikan di Kabupaten Pacitan, Jawa Timur. J. Teknologi Perikanan dan Kelautan, 4(2): 139-147. https://doi.org/10.24319/jtpk.4.139147

Hakim, L., E.S. Wiyono, \& R.I. Wahyu. 2018. Kompetisi alat penangkapan ikan skala kecil di Pelabuhan Perikanan Pantai (PPP) Tegalsari. $J$. Marine Fisheries, 9(1): 111-120. https://doi.org/10.29244/jmf.9.1.111120

Harahap, A.H., V.P. Siregar, \& S.B. Agus. 2019. Pola spasial dan temporal daerah penangkapan ikan pelagis menggunakan data oseanografi di Perairan Sumatera Barat. J. Ilmu dan Teknologi Kelautan Tropis, 11(2): 297-310. http://doi.org/10.29244/jitkt.v11i2.2 2590

Hufiadi, \& E.S. Wiyono. 2009. Tingkat kappasitas penangkapan armada pukat cincin di Pekalongan berdasarkan musim penangkapan. $J$. Penelitian Perikanan Indonesia, 15(4): 313-320.

http://doi.org/10.15578/jppi.15.4.200 9.313-320

King, M. 2007. Fisheries biology, assessment and management. 
Second Edition. Blackwell Publishing, Ltd. Australia. 15 p.

Le Pape, O. \& J. Vigneau. 2001. The influence of vessel size and fishing strategy on the fishing effort for multi-species fisheries in North Western France. ICES J. Marine Science, 58: 1232-1242. https://doi.org/10.1006/jmsc.2001.11 21

Malik, A., A. Rahim, U. Sideng, U. Rasyid, \& J. Jumaddin. 2019. Biodiversity assessment of mangrove vegetation for the sustainability of ecotourism in West Sulawesi, Indonesia. $A A C L$ International $J$. of the Bioflux Society, 12(4): 1458-1466.

http://www.bioflux.com.ro/docs/201 9.1458-1466.pdf

Matić-Skoko, S., N. Staglicic, A. Pallaoro, M. Kraljevic, J. Dulcic, P. Tutman, \& B. Dragicevic. 2011. Effectiveness of conventional management in Mediteranean type artisanal fisheries. Estuari Coastal Shelf Science, 91: 314-324. https://doi.org/10.1016/j.ecss.2010.1 0.029

Madau, F.A., L. Idda, \& P. Pulina. 2009. Capacity and economic efficiency in small-scale fisheries: evidence from Mediterranean Sea. Marine Policy, 33(5): 860-867.

https://doi.org/10.1016/j.marpol.200 9.03.006

Mc Clanahan, R., J.C. Castilla, A.T. White, \& O. Defeo. 2009. Healing smallscale fisheries by facilitating complex socio ecological systems. Fish Biologi and Fisheries, 19: 3347.

https://doi.org/10.1007/s11160-0089088-8

Mozumder, M.M.H., M.A. Wahab, S. Sarkki, P. Schneider, \& M.M. Islam. 2018. Enhancing social resilience of the coastal fishing communities: A case study of Hilsa
(Tenualosa Ilisha $H$ ) fishery in Bangladesh. J. Sustainability, 10(3501): 1-21. https://doi.org/10.3390/su10103501

Pomeroy, R.S. 2011. Managing overcapacity in small-scale fisheries in Southeast Asia. Marine Policy, 36: 520-527.

https://doi.org/10.1016/j.marpol.201 1.10 .002

Putten Van, I.E., S. Kulmala, O. Thebaud, N. Dowling, K.G. Hamon, T. Hutton, \& S. Pascoe. 2012. Theories and behavioural drivers underlying fleet dynamics models. Fish Fisheries, 13: 216-235.

https://doi.org/10.1111/j.14672979.2011.00430.x

Sari, W.K., E.S. Wiyono, \& R. Yusfiandayani. 2015. Kompetisi perikanan tangkap skala kecil di PPN Prigi, Jawa Timur. J. Penelitian Perikanan Indonesia, 21(4): 221228.

http://doi.org/10.15578/jppi.21.4.201 5.221-228

Sudarmo, A.P., M.S. Baskoro, B. Wiryawan, E.S. Wiyono, \& D.R. Monintja. 2015. Analysis of production factors of small-scale fisheries using arad nets in Tegal City, Indonesia. Developing Country Studies, 5(4): 98-104.

http://www.iiste.org/Journals/index.p hp/DCS/article/download/19659/201 28

Sudarmo, A.P., S.B. Mulyono, B. Wiryawan, E.S. Wiyono, \& D.R. Monintja. 2013. Perikanan skala kecil: proses pengambilan keputusan nelayan dalam kaitannya dengan faktor-faktor yang mempengaruhi penangkapan ikan. Marine Fisheries, 4(2): 195-200. https://doi.org/10.29244/jmf.4.2.195200

Soukota, M.L. 2013. Strategi pengembangan usaha bagan (lift net) di Desa 
Sathean, Kecamatan Kei Kecil, Kabupaten Maluku Tenggara. $J$. Triton, 9(2): 106-114.

Vatria, B., B. Wiryawan, E.S. Wiyono, \& M.S. Baskoro. 2019. Klasterisasi karakteristik perikanan tangkap skala kecil di Kabupaten Kayong Utara. $J$. Marine Fisheries, 10(1): 95-106. http://journal.ipb.ac.id/index.php/jps p/article/view/27999/17898

Wiyono, E.S., S. Yamada, E. Tanaka, \& T. Kitakado. 2006. Dynamics of fishing gear allocation by fishers in small-scale coastal fisheries of Pelabuhanratu Bay, Indonesia. Fisheries Management and Ecology, 13(3): 185-195. https://doi.org/10.1111/j.13652400.2006.00493.x

Wiyono, E.S. 2012. Landing characteristic of fishing gears in small-scale tropical coastal fisheries of Pelabuhanratu Bay, West Java, and its aplication for gear management.
J. Bumi Lestari, 12(2): 239-250. https://ojs.unud.ac.id/index.php/blje/ article/view/4811

Yulianto, S. \& K.H. Hidayatullah. 2014. Analisis cluster untuk pengelompokan Kabupaten/Kota di Provinsi Jawa Tengah berdasarkan indikator kesejahteraan rakyat. J. Statistika, 2(1): 56-63.

https://jurnal.unimus.ac.id/index.php /statistik/article/view/1115/1165

Yuniati, R.A.N. \& F. Rahman. 2017. Cluster potensi sektor perikanan pada perairan umum di Jawa Timur tahun 2016. Seminar Nasional Pendidikan, Sains dan Teknologi, Fakultas Matematika dan Ilmu Pengetahuan Alam, Universitas Muhamadiyah Semarang. 224-233 pp.

Received : 13 August 2020

Reviewed : 28 September 2020

Accepted : 27 November 2020 
